\title{
PENGARUH PEMBERIAN EKSTRAK KACANG HIJAU (PHASEOLUS RADIATUS) TERHADAP KADAR KOLESTEROL LDL SERUM TIKUS HIPERKOLESTEROLEMIA
}

\author{
Novi Cynthia PD, Enny Probosari*) \\ Program Studi Ilmu Gizi Fakultas Kedokteran Universitas Diponegoro \\ Jl.Dr.Sutomo No.18, Semarang, Telp (024) 8453708, Email : gizifk@undip.ac.id
}

\begin{abstract}
Background : Hypercholesterolemia is a risk factor for cardiovascular disease that remains the main cause of deaths in the world. Hypercholesterolemia can be managed throught diet modification. Mung bean extract contains isoflavone that may lower LDL cholesterol levels.

Objective : To analyze the effect of mung bean extract on serum LDL cholesterol levels of hypercholesterolemia Sprague Dawley rats.

Method : This research was a true-experimental using pre and post test with randomized control group design. Samples were 28 male rats which were induced hypercholesterolemia for 30 days and given mung bean extract at $0.45 \mathrm{gr} / \mathrm{kg}$ Weight, $0.95 \mathrm{gr} / \mathrm{kg}$ Weight and $1.35 \mathrm{gr} / \mathrm{kg}$ Weight dosages for 14 days. LDL cholesterol levels were measured by CHOD-PAP method. Data were analyzed using Paired T-Test and One Way Anova.

Result : LDL cholesterol decreased in $K, P 1$, and P3, but there was no significant result ( $p>0.05)$. The highest reduction of LDL cholesterol was 30.54\%, found in K, followed by $21.06 \%$ for P1 and $17.37 \%$ for P3. LDL cholesterol in group P2 can increased $2,88 \%$, but there was no significant result ( $p>0.05)$.

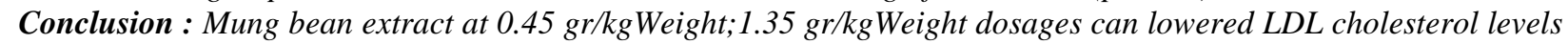
$21.06 \%$ and $17.37 \%$, but there is no significant result ( $p>0.05)$.
\end{abstract}

Key Words : Mung bean (Phaseolus radiatus), LDL Cholesterol, Hypercholesterolemia

\section{ABSTRAK}

Latar Belakang : Hiperkolesterolemia merupakan faktor risiko penyakit kardiovaskuler yang menjadi penyebab kematian utama di dunia. Pengendalian hiperkolesterolemia dapat dilakukan melalui modifikasi diet. Ekstrak kacang hijau mengandung isoflavon yang mampu menurunkan kadar kolesterol LDL.

Tujuan : Menganalisis pengaruh pemberian ekstrak kacang hijau terhadap kadar kolesterol LDL serum tikus Sprague Dawley hiperkolesterolemia.

Metode : Jenis penelitian ini adalah true-experimental dengan pre and post test with randomized control group design. Subjek penelitian yaitu 28 ekor tikus Sprague Dawley jantan yang diinduksi hiperkolesterolemia selama 30 hari, diberi ekstrak kacang hijau dengan dosis $0,45 \mathrm{gr} / \mathrm{kgBB} ; 0,9 \mathrm{gr} / \mathrm{kgBB}$; dan 1,35gr/kgBB per hari selama 14 hari. Kadar kolesterol LDL diperiksa dengan metode CHOD-PAP. Data dianalisis menggunakan uji Paired T-test dan One Way Anova.

Hasil : Kolesterol LDL menurun pada kelompok kontrol, P1, dan P3, tetapi penurunan tersebut tidak signifikan (p>0,05). Penurunan tertinggi sebesar 30,54\% pada kelompok kontrol, diikuti oleh P1 sebesar 21,06\% dan P3 sebesar 17,37\%. Kolesterol LDL pada P2 mengalami peningkatan sebesar 2,88\%, tetapi peningkatan tersebut tidak signifikan $(p>0,05)$.

Simpulan : Ekstrak kacang hijau pada dosis 0,45 gr/kgBB;1,35 gr/kgBB mampu menurunkan kadar kolesterol LDL sebesar 21,06\% dan 17,37\%, namun secara statistik tidak bermakna.

Kata Kunci :Kacang Hijau (Phaseolus radiatus), Kadar Kolesterol LDL, Hiperkolesterolemia

\section{PENDAHULUAN}

Penyakit kardiovaskuler merupakan penyebab kematian utama di dunia. Berdasarkan Survei Kesehatan Rumah Tangga (SKRT) tahun 2004 menunjukkan bahwa prevalensi penyakit jantung pada penduduk umur $\geq 15$ tahun sebesar $2,2 \%$ dan prevalensi gejala penyakit jantung sebesar 8,4\%. ${ }^{1}$ Laporan WHO tahun 2011, 17,5 juta orang meninggal dunia akibat penyakit kardiovaskuler atau $30 \%$ kematian di dunia. ${ }^{2}$

Aterosklerosis merupakan penyebab utama penyakit jantung koroner (PJK). Faktor risiko aterosklerosis terdiri dari 2 jenis, yaitu faktor risiko yang tidak dapat dikendalikan dan faktor risiko yang dapat dikendalikan. Faktor risiko yang tidak dapat dikendalikan adalah usia, jenis kelamin, dan genetik. Faktor risiko yang dapat dikendalikan adalah hiperkolesterolemia, hipertensi, diabetes mellitus, obesitas, dan aktivitas fisik kurang. ${ }^{3,4}$ Salah satu faktor risiko penyakit kardiovaskuler adalah hiperkolesterolemia.

Hiperkolesterolemia merupakan kondisi saat konsentrasi kolesterol di dalam darah melebihi batas normal. Hiperkolesterolemia terjadi akibat

${ }^{*}$ Penulis Penanggungjawab 
akumulasi kolesterol dan lipid pada dinding pembuluh darah. Kolesterol LDL-teroksidasi berperan dalam pembentukan plak aterosklerosis atau penyempitan pembuluh darah. ${ }^{5}$

Salah satu alternatif yang aman menurunkan kadar kolesterol LDL yaitu modifikasi pola diet. Diet yang dianjurkan adalah membatasi konsumsi makanan yang mengandung kolesterol dengan mengkonsumsi makanan yang bersifat antihiperkolesterolemia. Salah satu bahan makanan yang bersifat antihiperkolesterolemia adalah kacang hijau atau Phaseolus radiatus. ${ }^{6}$

Kacang hijau merupakan tumbuhan kacang-kacangan yang mudah dijumpai di Indonesia. Kacang hijau memiliki kandungan karbohidrat dan serat yang baik. Karbohidrat merupakan komponen terbesar dari kacang hijau yaitu sebesar 62-63\%. Kandungan lemak pada kacang hijau adalah 0,7-1 gr/kg kacang hijau segar yang terdiri atas $73 \%$ lemak tak jenuh dan $27 \%$ lemak jenuh, sehingga aman dikonsumsi oleh orang yang mengalami hiperkolesterolemia. ${ }^{7}$

Tumbuhan ini mengandung senyawa bioaktif isoflavon yang tinggi. Kadar isoflavon pada kacang hijau segar adalah $70,74 \mathrm{mg}$ per 100 gr bahan. ${ }^{8}$ Pada penelitian sebelumnya, isoflavon terbukti mampu menurunkan kadar kolesterol darah. Penelitian tentang ekstrak kacang hijau dan pengaruhnya terhadap kadar kolesterol LDL belum pernah dilakukan.

Kandungan zat gizi yang terkandung pada kacang hijau hampir sama dengan kedelai. Kandungan energi pada kacang hijau adalah 345 kkal/100 gr bahan sedangkan pada kedelai adalah $331 \mathrm{kkal} / 100$ gr bahan. Kacang hijau mengandung protein sebesar 22,2 gr/100 gr bahan dan kedelai sebesar 34,9 gr/100 gr bahan. Lemak pada kacang hijau lebih rendah dibandingkan kedelai, yaitu 1,2 gr/100 gr bahan dan kedelai 18,1 gr/100 gr bahan. ${ }^{7}$ Penelitian ini mengacu dengan penelitian sebelumnya mengenai pemberian ekstrak kedelai terhadap kolesterol dengan dosis $0,45 \mathrm{gr} / \mathrm{kgBB}$; $0,9 \mathrm{gr} / \mathrm{kgBB} ;$ dan $1,35 \mathrm{gr} / \mathrm{kgBB} .^{9}$

Penelitian mengenai ekstrak kedelai telah terbukti dapat menurunkan kolesterol LDL pada tikus putih yang mengalami hiperkolesterolemia meskipun tidak signifikan. ${ }^{10}$ Sebuah metaanalisis 11 uji klinis pada manusia menyimpulkan bahwa konsumsi kedelai sebanyak $102 \mathrm{mg} / \mathrm{hari}$ dapat menurunkan kadar LDL sebesar 4,98\% dan meningkatkan kadar HDL sebesar 3,00\% secara signifikan. ${ }^{11}$ Sebuah metaanalisis 23 uji klinis pada manusia juga melaporkan bahwa konsumsi isoflavon $>80 \mathrm{mg} / \mathrm{hari}$ dapat menurunkan kolesterol total sebesar 3,77\%, kolesterol LDL sebesar 5,25\%, triasilgliserol sebesar 7,27\% dan secara signifikan meningkatkan kolesterol HDL sebesar 3,03\%. ${ }^{12}$ Penelitian lain juga menyimpulkan bahwa konsumsi kedelai dengan tinggi isoflavon menurunkan kolesterol LDL lebih banyak dibandingkan dengan konsumsi kedelai dalam jumlah yang sama dengan rendah isoflavon. $^{13}$

Hal ini mendorong peneliti untuk mengkaji lebih jauh mengenai pengaruh pemberian ekstrak kacang hijau (Phaseolus radiatus) terhadap kadar kolesterol LDL tikus Sprague Dawley hiperkolesterolemia.

\section{METODE}

Penelitian yang dilakukan di Laboratorium Penelitian dan Pengujian Terpadu (LPPT) Universitas Gajah Mada ini merupakan penelitian jenis true eksperimental dengan rancangan Pre and Post Test Randomized Controlled Group Design. Variabel bebas pada penelitian ini adalah pemberian ekstrak kacang hijau dalam berbagai dosis dan variabel terikat adalah perubahan kadar kolesterol LDL.

Sampel yang digunakan adalah tikus putih (Rattus novergicus) galur Sprague Dawley berjenis kelamin jantan, umur 8 minggu, berat badan 150220 gram yang diperoleh dari Laboratorium Penelitian dan Pengujian Terpadu (LPPT) Universitas Gajah Mada. Besar sampel minimal pada penelitian ini menggunakan ketentuan WHO, dimana jumlah minimal sampel per kelompok adalah 5 ekor. ${ }^{14}$ Pada penelitian ini menggunakan 7 ekor tikus tiap kelompok perlakuan untuk mengantisipasi drop out. Kelompok pada penelitian ini terdiri dari kelompok kontrol, kelompok perlakuan dosis $0,45 \mathrm{gr} / \mathrm{kgBB}$, kelompok perlakuan dosis $0,9 \mathrm{gr} / \mathrm{kgBB}$, dan kelompok perlakuan dosis $1,35 \mathrm{gr} / \mathrm{kgBB}$. Jumlah tikus yang digunakan adalah 28 ekor.

Sampel dibagi menjadi 4 kelompok secara random. Kelompok kontrol dan kelompok perlakuan diberi pakan standar serta pakan tinggi kolesterol selama 30 hari untuk membuat tikus menjadi hiperkolesterolemia.

Pakan standar yang diberikan menggunakan pakan AD II. Dalam 100 gram pakan standar mengandung karbohidrat $51 \%$, protein kasar $15 \%$, lemak kasar 3-7\%, serat kasar 6\%, abu $7 \%$, kalsium $0,9-11 \%$, phosphor $0,6-0,9 \%$, air $12 \%$, antibiotika, dan coccidiostat sebanyak $20 \mathrm{mg} / \mathrm{hari}$, sedangkan pakan tinggi kolesterol menggunakan 
kuning telur bebek mentah $4 \mathrm{ml} /$ hari dan lemak babi $1,5 \mathrm{ml} /$ hari.

Pengambilan darah awal pada sampel bertujuan untuk mengetahui kadar kolesterol LDL setelah pemberian pakan tinggi kolesterol selama 30 hari, sedangkan kadar kolesterol LDL akhir didapat setelah pemberian ekstrak kacang hijau selama 14 hari. Sampel darah diambil sebanyak 2 $\mathrm{ml}$ melalui pleksus retroorbitalis, kemudian disentrifuge untuk mendapatkan serumnya. Kolesterol LDL ditentukan dengan metode CHODPAP.
Data yang dikumpulkan meliputi perhitungan jumlah asupan standar, pemantauan berat badan tikus setiap 7 hari sekali untuk masingmasing perlakuan dan data kadar kolesterol LDL hiperkolesterolemia dan akhir. Data yang diperoleh diuji normalitasnya dengan uji Shapiro-Wilk. Perbedaan kadar kolesterol LDL sebelum dan sesudah perlakuan menggunakan uji statisitik parametrik Paired t-test. Perbedaan pengaruh ekstrak kacang hijau terhadap kadar kolesterol LDL seluruh kelompok perlakuan dengan berbagai dosis dianalisis menggunakan uji statistik parametrik One Way Anova.

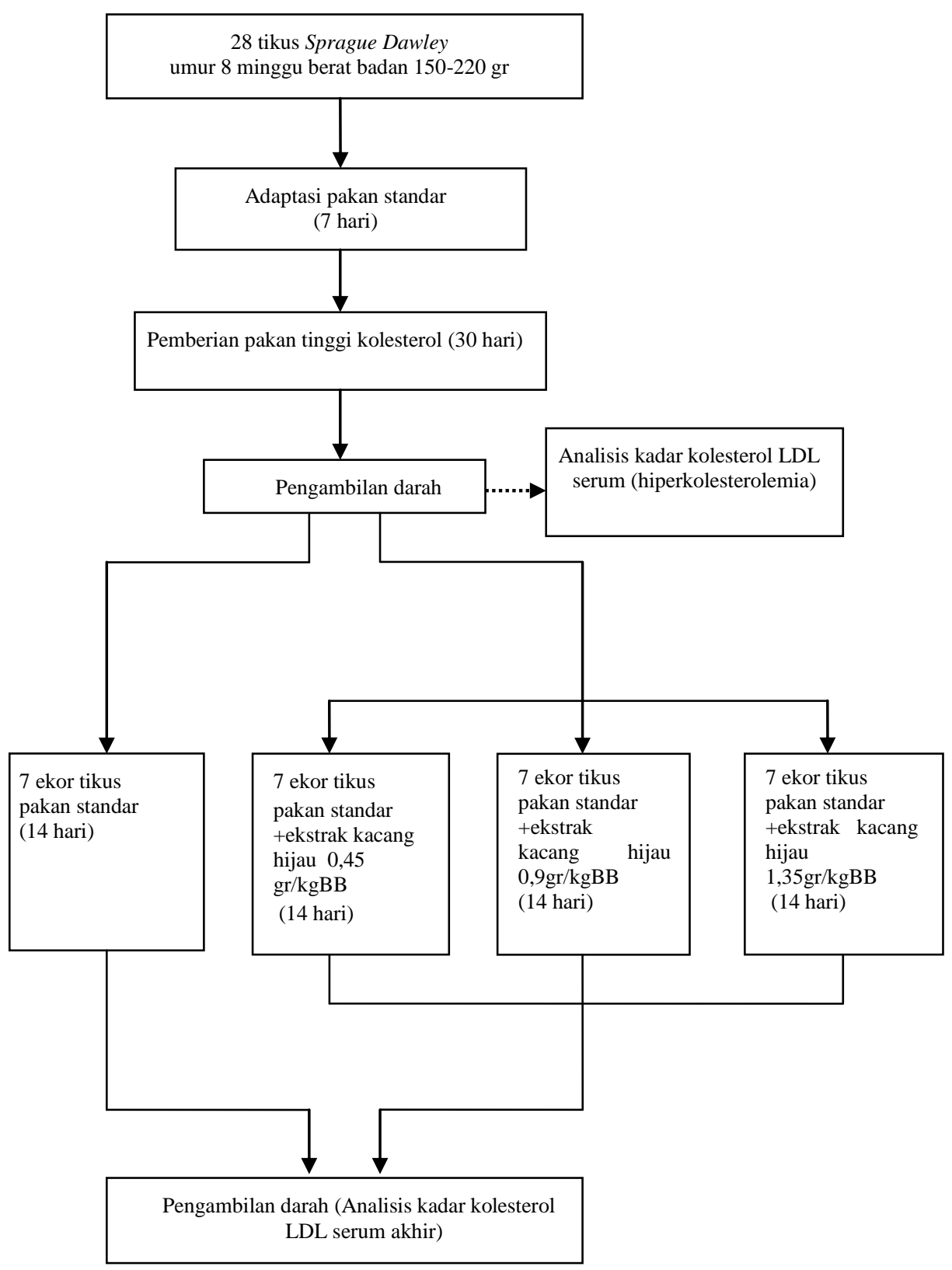

Gambar 1. Alur Kerja Penelitian 


\section{HASIL PENELITIAN}

\section{Karakteristik Sampel}

Sampel pada penelitian ini adalah 28 ekor tikus Sprague Dawley berjenis kelamin jantan, usia 8 minggu dengan berat badan berkisar antara 150220 gram. Sampel dipelihara dalam kandang individu. Pada saat perlakuan, terjadi drop out pada masing-masing kelompok sehingga jumlah sampel menjadi 24 ekor.

\section{Berat badan, Asupan makan, dan Total kalori}

Berdasarkan hasil penelitian, didapatkan gambaran rerata berat badan tikus sebelum dan sesudah perlakuan yang tersaji dalam tabel di bawah ini.

Tabel 1. Rerata Berat Badan Tikus Jantan Sprague Dawley

\begin{tabular}{|c|c|c|c|c|c|c|}
\hline \multirow[b]{2}{*}{ Kelompok } & \multirow[b]{2}{*}{$\mathbf{N}$} & \multicolumn{2}{|c|}{ Rerata $($ gr $) \pm$ SD } & \multirow[b]{2}{*}{$\Delta$} & \multirow[b]{2}{*}{$\begin{array}{l}\Delta \\
\%\end{array}$} & \multirow[b]{2}{*}{$p$} \\
\hline & & $\begin{array}{c}\text { Sebelum } \\
\text { Perlakua } \\
\text { n }\end{array}$ & $\begin{array}{c}\text { Setelah } \\
\text { Perlakua } \\
\text { n }\end{array}$ & & & \\
\hline K & 6 & $\begin{array}{c}208.6 \pm 18 \\
2\end{array}$ & $\begin{array}{c}270.3 \pm 20 \\
5\end{array}$ & 61.7 & 29.57 & $0.000^{*}$ \\
\hline P1 & 6 & $\begin{array}{c}194.5 \pm 15 \\
1\end{array}$ & $\begin{array}{c}259.4 \pm 13 \\
1\end{array}$ & 60.1 & 30.89 & $0.000 *$ \\
\hline $\mathrm{P} 2$ & 6 & $\begin{array}{c}199.1 \pm \\
9.2\end{array}$ & $\begin{array}{c}263.5 \pm \\
9.1\end{array}$ & 63.2 & 31.74 & $0.000^{*}$ \\
\hline P3 & 6 & $\begin{array}{c}208.6 \pm 13 \\
1\end{array}$ & $\begin{array}{c}264.1 \pm 21 . \\
6\end{array}$ & 66.0 & 31.64 & $0.001 *$ \\
\hline
\end{tabular}

*memiliki perbedaan yang bermakna $(p<0,05)$

Keterangan : K : kelompok kontrol

P1 : kelompok perlakuan dosis $0,45 \mathrm{gr} / \mathrm{kgBB}$

$\mathrm{P} 2$ : kelompok perlakuan dosis $0,9 \mathrm{gr} / \mathrm{kgBB}$

P3 : kelompok perlakuan dosis $1,35 \mathrm{gr} / \mathrm{kgBB}$

Tabel 1 menunjukkan bahwa seluruh kelompok sampel mengalami peningkatan rerata berat badan sebelum dan sesudah perlakuan. Peningkatan tertinggi terdapat pada kelompok P2 sebesar 31,74\%. Hasil analisis menunjukkan adanya peningkatan berat badan seluruh kelompok secara bermakna $(p<0,05)$.

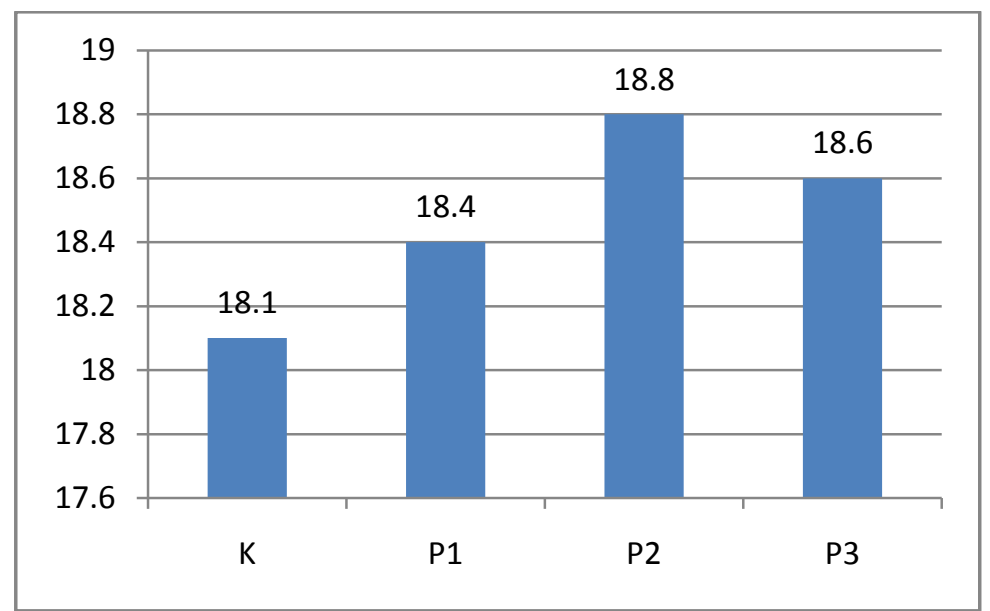

Gambar 2. Diagram asupan makan pada masing-masing kelompok

Gambar 2 menunjukkan bahwa rerata asupan makan tertinggi adalah kelompok P2 sebesar 18,8 gram, sedangkan yang terendah adalah kelompok kontrol sebesar 18,1 gram, sehingga dapat disimpulkan bahwa faktor pendorong peningkatan berat badan sampel adalah banyaknya asupan makan. 
Tabel 2. Rerata Total Kalori Sebelum dan Sesudah Pemberian Ekstrak Kacang Hijau

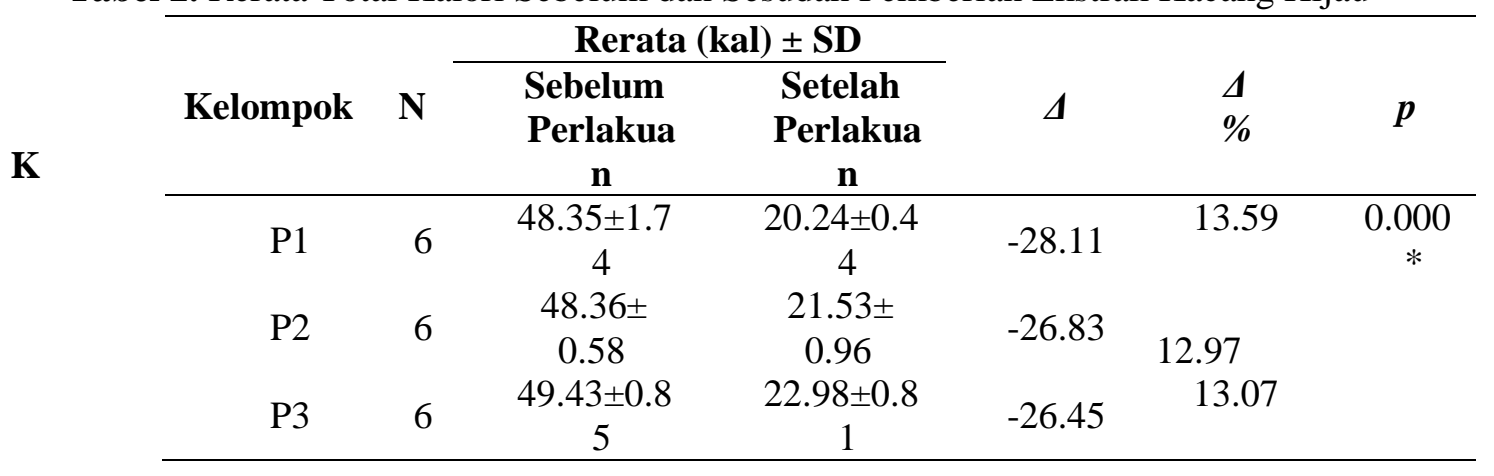

*memiliki perbedaan yang bermakna $(p<0,05)$

Tabel 2 menunjukkan bahwa total kalori yang diasup kelompok P1, P2, dan P3 sebelum dan sesudah pemberian ekstrak kacang hijau memiliki perbedaan yang bermakna $(\mathrm{p}<0.05)$. Penurunan total kalori tertinggi terdapat pada kelompok P1 sebesar $13.59 \%$, sedangkan penurunan total kalori terendah terdapat pada kelompok P2 sebesar $12.97 \%$.

Pada uji wilcoxon menunjukkan bahwa penurunan total kalori sebelum dan sesudah pemberian ekstrak kacang hijau memiliki perbedaan yang bermakna $(p=0,000)$, sedangkan uji Mann-Whitney dilakukan untuk mengetahui perbedaan total kalori antar kelompok P1, P2, dan P3. Hasil tersebut menunjukkan bahwa terdapat perbedaan yang bermakna $(p=0,037)$ antara $\mathrm{P} 1$ dan $\mathrm{P} 2$, terdapat perbedaan yang bermakna $(p=0,004)$ antara $\mathrm{P} 1$ dan $\mathrm{P} 3$, serta tidak terdapat perbedaan yang bermakna $(p=0,25)$ antara $\mathrm{P} 2$ dan $\mathrm{P} 3$.

\section{Kadar Kolesterol LDL Setelah Pemberian Ekstrak Kacang Hijau}

Berdasarkan hasil penelitian, didapatkan gambaran rerata kadar kolesterol LDL sebelum dan sesudah perlakuan.

Tabel 3. Kadar Kolesterol LDL Setelah Pemberian Ekstrak Kacang Hijau

\begin{tabular}{|c|c|c|c|c|c|c|}
\hline \multirow[b]{2}{*}{ Kelompok } & \multicolumn{3}{|c|}{ Rerata(mg/dl) \pm SD } & \multirow[b]{2}{*}{$\Delta$} & \multirow[b]{2}{*}{$\begin{array}{l}\Delta \\
\%\end{array}$} & \multirow[b]{2}{*}{$p$} \\
\hline & $\mathbf{N}$ & $\begin{array}{c}\text { Sebelum } \\
\text { Perlakua } \\
\text { n }\end{array}$ & $\begin{array}{c}\text { Setelah } \\
\text { Perlakua } \\
\text { n }\end{array}$ & & & \\
\hline $\mathrm{K}$ & 6 & $\begin{array}{c}25.96 \pm 2.4 \\
4\end{array}$ & $\begin{array}{c}18.03 \pm 3.4 \\
3\end{array}$ & $\begin{array}{c}- \\
7.9 \\
3\end{array}$ & 30.54 & 0.063 \\
\hline $\mathrm{P} 1$ & 6 & $\begin{array}{c}28.96 \pm 7.6 \\
8\end{array}$ & $\begin{array}{c}22.86 \pm 5.4 \\
7\end{array}$ & $\begin{array}{c}- \\
6.1 \\
0\end{array}$ & 21.06 & 0.262 \\
\hline $\mathrm{P} 2$ & 6 & $\begin{array}{c}19.45 \pm 7.8 \\
4\end{array}$ & $\begin{array}{c}20.01 \pm 8.1 \\
1\end{array}$ & 0.56 & 2.88 & 0.905 \\
\hline P3 & 6 & $\begin{array}{c}24.06 \pm 4.7 \\
8\end{array}$ & $\begin{array}{c}19.88 \pm 6.6 \\
6\end{array}$ & $\begin{array}{c}- \\
4,1 \\
8\end{array}$ & 17.37 & 0.317 \\
\hline
\end{tabular}

Tabel 3 menunjukkan adanya penurunan kadar kolesterol LDL. Penurunan tersebut terjadi pada kelompok kontrol, P1 dan P3 meskipun secara statistik tidak bermakna.

Hasil analisis menunjukkan bahwa terdapat penurunan kadar kolesterol LDL antara kelompok tanpa ekstrak kacang hijau dan kelompok yang diberi ekstrak kacang hijau. Kelompok tanpa ekstrak kacang hijau mengalami penurunan kadar kolesterol LDL sebesar 30,54\%, kelompok P1 sebesar 21,06\% dan kelompok P3 sebesar 17,37\%, sedangkan kelompok P2 mengalami peningkatan kadar kolesterol LDL sebesar $2,88 \%$.

\section{PEMBAHASAN \\ Berat Badan Subjek}


Penimbangan berat badan dilakukan 7 hari sekali dan penimbangan sisa pakan dilakukan setiap hari. Hasil pengukuran berat badan menunjukkan adanya perbedaan berat badan sebelum dan sesudah perlakuan. Berat badan sebelum dan sesudah perlakuan mengalami peningkatan meskipun secara statistik tidak bermakna. Selama 30 hari semua kelompok kontrol dan perlakuan mendapat pakan standar (pakan AD II) dan pakan tinggi kolesterol (kuning telur bebek dan lemak babi). Semua sampel mengalami peningkatan berat badan. Setelah selesai pemberian pakan tinggi kolesterol, kelompok kontrol hanya mendapatkan pakan standar dengan jumlah yang sama dengan kelompok perlakuan, sedangkan kelompok P1, P2, dan P3 mendapat pakan standar dan ekstrak kacang hijau.

Peningkatan berat badan tertinggi terdapat pada kelompok P2 sebesar $31,74 \%$. Hal ini dipengaruhi oleh paling tingginya asupan makan pada kelompok tersebut, yaitu 18,8 gram.

Pada penelitian ini juga dilakukan perhitungan total kalori pada kelompok P1, P2, dan P3, sedangkan kelompok kontrol tidak dihitung dikarenakan hanya mengonsumsi pakan standar dan pakan tinggi kolesterol. Total kalori juga dimungkinkan mempengaruhi berat badan kelompok perlakuan. Tingginya total kalori akan meningkatkan berat badan pula.

\section{Kadar Kolesterol LDL Setelah Pemberian Pakan Tinggi Kolesterol}

Pakan tinggi kolesterol yang digunakan dalam penelitian ini adalah kuning telur bebek mentah dan lemak babi. Kuning telur bebek $4 \mathrm{ml} / \mathrm{ekor} / \mathrm{hari}$ dicampur lemak babi $1,5 \mathrm{ml} / \mathrm{ekor} / \mathrm{hari}$ dan ditambah aquadest $1,5 \mathrm{ml} / \mathrm{ekor} / \mathrm{hari}$. Larutan tersebut kemudian disaring dan diinduksi ke tikus dengan cara sonde. Kuning telur bebek mengandung 17 gr protein, 35 gr lemak dan kolesterol $884 \mathrm{mg} / 100$ gr sehingga diharapkan mampu meningkatkan kadar kolesterol LDL. ${ }^{15}$ Lemak babi mengandung $2 \%$ asam lemak miristat, $25 \%$ asam lemak palmitat, $15 \%$ asam lemak stearat, $45 \%$ asam lemak oleat, dan $9 \%$ asam lemak linoleat. ${ }^{16}$

Setelah selesai pemberian pakan tinggi kolesterol selama 30 hari, peneliti mengukur kadar kolesterol LDL pada semua sampel. Sampel yang memiliki kolesterol total $>54 \mathrm{mg} / \mathrm{dl}$ diambil sebagai kelompok kontrol dan perlakuan. Kolesterol total $>54 \mathrm{mg} / \mathrm{dl}$ dapat diartikan sampel mengalami kondisi hiperkolesterolemia, sedangkan sampel yang memiliki kolesterol total $<54 \mathrm{mg} / \mathrm{dl}$ tidak mengalami kondisi hiperkolesterolemia, sehingga dilakukan drop out. Jumlah sampel yang di drop out adalah 4 ekor tikus, sehingga sampel yang digunakan dalam kelompok perlakuan sebanyak 24 ekor. Asupan tinggi lemak jenuh dan kolesterol dapat meningkatkan konsentrasi kolesterol karena selain dari asupan, kolesterol juga dapat disintesis oleh tubuh sendiri. Kandungan lemak jenuh meningkatkan kadar LDL melalui mekanisme penurunan sintesis dan aktivitas reseptor LDL. ${ }^{17}$ Asam lemak jenuh mempengaruhi kadar LDL dalam darah dengan memperlambat clearance trigliserida pada mekanisme reverse cholesterol transport yang membawa kolesterol dari jaringan ke hati. ${ }^{18}$ Sebuah penelitian menunjukkan bahwa setiap asupan lemak jenuh 1\% dari total energi sehari dapat meningkatkan 2,7 $\mathrm{mg} / \mathrm{dl}$ kadar kolesterol. ${ }^{19}$

\section{Kadar Kolesterol LDL Setelah Pemberian Ekstrak Kacang Hijau}

Kelompok P1 dan P3 mengalami penurunan kadar kolesterol LDL sebesar 21,06\% dan $17,37 \%$. Penurunan tersebut kemungkinan disebabkan oleh asupan makan yang rendah. Asupan makan mempengaruhi perubahan total kalori sebelum dan sesudah pemberian ekstrak kacang hijau. Rerata perubahan total kalori pada kelompok P1(13,59\%) dan P3(13,07\%) lebih tinggi dibandingkan P2(12,97\%). Perubahan total kalori yang lebih tinggi pada kelompok P1 dan P3 diartikan bahwa kedua kelompok tersebut memiliki total kalori yang lebih rendah dibandingkan P2.

Total kalori merupakan jumlah kalori yang diperoleh dari asupan makan selama satu hari. Metabolisme tubuh membutuhkan kalori dari makanan untuk diproses, sehingga hasil metabolisme dapat digunakan atau disimpan dalam tubuh. $^{20}$ Total kalori yang lebih rendah pada kelompok P1 dan P3 dibandingkan P2 kemungkinan berdampak pada metabolisme lemak. Apabila total kalori yang diasup rendah, kadar triasilgliserol yang merupakan hasil metabolisme lemak juga akan rendah. Triasilgliserol bergabung dengan kolesterol di dalam hati dan disintesis menjadi VLDL. VLDL mengalami proses penguraian lipid secara bertahap. Saat lemak disalurkan ke jaringan, VLDL lebih diperkaya kolesterol dan berubah menjadi LDL. LDL merupakan pembawa kolesterol terbesar. ${ }^{21}$ Karena total kalori pada kelompok P1 dan P3 rendah, maka hasil metabolisme lemak juga akan rendah dan menyebabkan kadar kolesterol LDL menurun.

Selain total kalori, kemungkinan penurunan kadar kolesterol LDL pada kelompok 
P1 dan P3 adalah kandungan lemak pada kacang hijau sebanyak $0,7-1 \mathrm{gr} / \mathrm{kg}$ bahan yang tersusun dari $73 \%$ asam lemak tak jenuh dan $27 \%$ asam lemak jenuh. PUFA (polyunsaturated fatty acid) yang terkandung di dalam lemak kacang hijau memiliki kemampuan untuk menurunkan kadar kolesterol LDL karena dapat meningkatkan jumlah reseptor LDL dan menurunkan sekresi VLDL dari hati. $^{7}$

Kacang hijau juga mengandung isoflavon sebesar $70,74 \mathrm{mg}$ per $100 \mathrm{gr}$ bahan. ${ }^{8}$ Sebuah metaanalisis menemukan bahwa kandungan isoflavon yang tinggi pada asupan makanan dapat menurunkan serum LDL kolesterol dibanding dengan yang rendah. Isoflavon yang terkandung dalam kacang hijau merupakan sterol yang berasal dari tumbuhan (fitosterol) yang apabila dikonsumsi dapat menghambat absorbsi kolesterol, baik yang berasal dari diet maupun kolesterol yang diproduksi oleh hati. ${ }^{10}$

Penurunan kolesterol oleh isoflavon terjadi karena pengaruh peningkatan katabolisme sel lemak dalam pembentukan energi yang berakibat pada penurunan kadar kolesterol. Isoflavon dapat mengaktifkan enzim sitokrom P-450 dimana enzim ini mampu mengikat kolesterol menuju asam empedu, sehingga dapat meningkatkan ekskresi asam empedu dan menurunkan kadar kolesterol darah. Isoflavon berperan dalam menekan konsentrasi triasilgliserol dalam darah dan hati melalui sintesis cAMP. Aktivasi enzim dan protein cAMP dapat meningkatkan hidrolisis triasilgliserol dan meningkatkan jumlah reseptor LDL (apo B100 dan apo E), sehingga konsentrasi kolesterol LDL menurun. ${ }^{22}$

Kelompok P2 mengalami peningkatan kadar kolesterol LDL sebesar 2,88\%. Peningkatan tersebut dimungkinkan karena rerata perubahan total kalori sebelum dan sesudah pemberian ekstrak kacang hijau paling rendah dibandingkan P1 dan P3. Perubahan total kalori paling rendah artinya pada kelompok P2 memiliki total kalori yang paling tinggi dibandingkan kelompok P1 dan P3. Sama seperti pada kelompok P1 dan P3, total kalori mempengaruhi metabolisme lemak. Total kalori yang paling tinggi pada kelompok P2 kemungkinan menyebabkan hasil metabolisme lemak (triasilgliserol) sudah mencukupi kebutuhan lemak dalam tubuh dan sisanya disimpan di jaringan adiposa sebagai cadangan lemak. Akibatnya, simpanan lemak dalam tubuh akan semakin diperkaya kolesterol. Hal tersebut menyebabkan meningkatnya kadar kolesterol LDL dalam darah.
Kelompok kontrol (tanpa ekstrak kacang hijau) pada penelitian ini mengalami penurunan kadar kolesterol LDL. Asupan makan pada kelompok kontrol lebih rendah dibandingkan P1, P2, dan P3. Hal ini dimungkinkan karena rendahnya kandungan lemak (3-7\%) dalam pakan standar. Lemak digunakan dalam proses metabolisme tubuh, sehingga apabila lemak yang diasup rendah, maka lemak yang digunakan sebagai cadangan tidak ada dan hanya dapat digunakan untuk menghasilkan energi terutama untuk aktivitas fisik. Kolesterol yang terkandung dalam lipid plasma juga rendah karena kurangnya bahan utama untuk proses metabolisme tubuh. ${ }^{20}$ Jadi, penurunan kadar kolesterol LDL pada kelompok kontrol kemungkinan disebabkan oleh kandungan lemak yang rendah dalam pakan standar meskipun penurunan tersebut secara statistik tidak bermakna.

\section{SIMPULAN}

Pemberian ekstrak kacang hijau selama 14 hari pada kelompok perlakuan dengan dosis 0,45 gr/kgBB dan $1,35 \mathrm{gr} / \mathrm{kgBB}$ mampu menurunkan kadar kolesterol LDL masing-masing sebesar $21,06 \%$ dan $17,37 \%$, tetapi penurunan tersebut secara statistik tidak bermakna.

\section{UCAPAN TERIMA KASIH}

Puji dan syukur penulis panjatkan kehadirat Allah SWT atas segala rahmat yang diberikan-Nya. Penulis mengucapkan terima kasih kepada dr.Yekti Wirawanni dan dr.Niken Puruhita,M.Med.Sc.,Sp.GK atas masukan dan saran yang telah diberikan. Ucapan terima kasih juga disampaikan kepada LPPT UGM atas bantuan dan kerjasama selama pelaksanaan penelitian, kepada Bapak Samidi dan Bapak Suroso selaku teknisi laboratorium hewan coba LPPT UGM yang telah banyak membantu dan memberikan masukan kepada peneliti dalam pelaksanan penelitian.

\section{DAFTAR PUSTAKA}

1. Pradono J, Sari P, Hapsari D, Suriani O, Lubis A, Afifah T, et al. Survei Kesehatan Nasional. Survei Kesehatan Rumah Tangga (SKRT) 2004. Volume 3 : Sudut pandang masyarakat mengena status, cakupan, ketanggapan, dan sistem pelayanan kesehatan. Jakarta : Badan Penelitian dan Pengembangan Kesehatan; 2004.

2. Sri Sumarti. Faktor-faktor Risiko Penyakit Jantung Koroner pada Usia Dewasa Muda yang Dirawat di Instalasi Jantung dan Pembuluh Darah Rumah Sakit Dokter Kariadi. Semarang: Universitas Diponegoro; 2010. 
3. Price SA, Wilson LM. Gangguan Sistem Kardiovaskuler. In : Hartanto $\mathrm{H}$, Susi $\mathrm{N}$, Wulansari P, Mahanani DA (eds). Patofisiologi : Konsep Klinis Proses-Proses Penyakit. Edisi 6. Jakarta: EGC; 2005.p.580-84

4. Mahan LK, Escott-Stump S, Raymond JL. Medical Nutrition Therapy for Cardivascular. In : Alexopoulus Y, editor. Krause's Food and the Nutrition Care Process. 13th ed. Saunders : Elsevier; 2012.p.750-52.

5. Albert AD, Battaglia KB. The role of cholesterol in rod outer segment membranes. Progress in Lipid Research 2005;44: 99-124.

6. Varady KA, Kones PJH. Combination diet and exercise inteventions for the treatment of dyslipidemia: an efective preliminary strategy to lower cholesterol levels. The journal of nutrition 2005;135:1829-35.

7. Robinson D, Singh DN. Alternative Protein Sources for Lying Hens. A Report for the Rural Industries Research and Development Corporation. Queensland Poultry Research and Development Centre 2001;1- 3.

8. Iswandari R. Studi Kandungan Isoflavon pada Kacang Hijau, Tempe Kacang Hijau, dan Bubur Kacang Hijau. Karya Tulis Ilmiah. Semarang: Fakultas Kedokteran Universitas Diponegoro; 2008.

9. Rachim W. Pengaruh Pemberian Ekstrak Kedelai terhadap Penurunan Kadar Kolesterol Total. Karya Tulis Ilmiah. Semarang: Universitas Islam Sultan Agung; 2012.

10. Hapsari AI, Poernomo B, Dhamayanti Y. Perbandingan efek pemberian sari kedelai kuning dan hitam terhadap rasio kolesterol LDL/HDL darah tikus putih (Rattus norvegicus) dengan diet tinggi lemak. Artikel Ilmiah. Surabaya: FKH Universitas Airlangga; 2009.

11. Taku K, Umegaki K, Sato K, et al. Soy isoflavones lower serum total and LDL cholesterol in humans: a meta-analysis of 11 randomized controlled trials. Am J Clin Nutr 2007;85:1148 -56.

12. Zhan S, Ho SC. Meta-analysis of the effects of soy protein containing isoflavones on the lipid. Am J Clin Nutr 2005;81:397-408.

13. Zhuo XG, Melby MK, Watanabe S. Soy isoflavone intake lowers serum LDL cholesterol: a meta-analysis of 8 randomized controlled trials in humans. J Nutr 2004;134:2395-400.

14. World Health Organization (WHO). General Guidelines for Methodologies

on Research and Evaluation of Traditional Medicine. Geneva : WHO; 2001.

15. Badan ketahanan pangan dan penyuluhan provinsi DIY. Kandungan gizi bahan pangan dan hasil olahannya (golongan IV: telur). Yogyakarta: 2011.p.10.
16. Diyan Y. Pengaruh pemberian nata de coco terhadap kadar kolesterol LDL

dan HDL pada tikus hiperkolesterolemia. Artikel Ilmiah. Semarang:

Program Studi Ilmu Gizi Fakultas Kedokteran Universitas Diponegoro; 2011.

17. Anwar TM, Linda EK, Lawrence K, Eva L, Vlad $\mathrm{V}$, Ruby J, et al. Interrelation of saturated fat, trans fat, alcohol intake, and subclinical atherosclerosis. Am J Clin Nutr 2008;87:168-74.

18. J Bruce German and Cora J Dillard. Saturated fats: what dietary intake?

Am J Clin Nutr 2004;80:550-9.

19. Soeharto I. Serangan Jantung dan Stroke. Jakarta: PT Gramedia Pustaka Utama; 2004.p.51-5.

20. Murray RK, Granner DK, Rodwell VW. Tinjauan Umum Metabolisme \& Penyediaan Bahan Bakar Metabolik. In : Wulandari N, Rendy L, et.al (eds). Biokimia Harper. Edisi 27. Jakarta : EGC; 2009.p.139-44.

21. Suyatna FD. Farmakologi dan Terapi: Hiperlipidemia. Edisi 5. Jakarta: Balai Penerbit FKUI; 2007.p.373-88.

22. Middleton E, Kandaswami C, Theoharides TC. The Effects of Plant Flavonoids on Mammalian Cells: Implications for Inflammation, Heart Disease, and Cancer Pharmacol Rev; 2000; 52: 673-751. 